\title{
JoECCE
}

Journal of Early Childhood and Character Education

Vol 1, No : 2, 2021

\section{Mengatasi Anak Trantrum Dengan Media Melukis Pada Masa Pandemi}

\author{
Siti Aisyah \\ Cahayaaisyah19@gmail.com,
}

Anita Afrianingsih

anita@unisnu.ac.id

Fakultas Pendidikan Guru Pendidikan Anak Usia Dini

UNISNU Jepara

\begin{abstract}
Temper trantum is an uncontrolled emotional outburst in children. Many parents do not know this term. Early childhood is a child who is just learning to know himself, including his emotional social. Counselors in counseling sessions must have various skills to help reveal the counselee's problems or desires, one way to reveal the counselee's problems can be done using painting. Painting is very appropriate to express various things that are difficult for the counselee to express verbally and in writing. Good counseling is with art, because it is more in harmony with the humanities than with science (Hansen, 2012). This research approach uses the observation method and the actions of parents. In this study, the subject cried because he did not want to do his BDR homework and wanted to play by bathing his chickens, but his parents prevented him from crying and throwing things around him. In this study counseling provides painting therapy on the subject and the subject responds well.
\end{abstract}

Keywords : Counseling; through painting media. 


\section{Abstrak}

Temper trantum merupakan suatu bentuk luapan emosi yang tidak terkontrol pada anak. Masih Banyak di Indonesia orangtua belum mengenal istilah ini. Anak usia dini merupakan anak yang baru belajar mengenal dirinya sendiri, termasuk sosial emosionalnya. Konselor dalam sesi konseling harus memiliki berbagai cara keterampilan untuk membantu mengungkap permasalahan ataupun keinginan konseli, salah satu cara mengungkap permasalahan konseli dapat dilakukan menggunakan lukisan. Lukisan sangat tepat untuk mengepresikan berbagai hal yang sulit diungkapkan konseli secara verbal maupun tulisan Konseling yang baik adalah dengan seni, karena lebih selaras dengan humaniora dibandingkan dengan ilmu pengetahuan (Hansen, 2012). Pendekatan penelitian ini menggunakan metode Observasi dan tindakan orang tua. Pada penelitian ini subyek menangis karena tidak ingin mengerjakan PR BDRnya daningin bermain dengan memandikan ayamnya, akan tetapi orangtuanya mencegahnya sehingga ia menangis dan melempar-lempar barang yang ada di sekitarnya. Dalam penelitian ini konseling memberikan terapi Melukis Pada subyek dan subyek merespon dengan baik.

Kata kunci:Konseling; melalui media melukis. 


\section{9 \\ PENDAHULUAN}

Anak usia empat tahun sudah berkembang kemampuan kognitifnya namun juga ada yang memiliki keterbatasan pada aspek bahasa. Ada yang mengalami kesulitan dalam menterjemahkan keinginan dalam bentuk bahasa sederhana yang mudah untuk kita pahami. Sehingga dengan kondisi tersebut, mereka merasa tidak nyaman dan tertekan yang mendorong emosi anak memuncak bahkan menjadikan rasa kecewa yang berakibat secara tidak langsung menjadi frustasi anak dalam bentuk sikap tantrum.

Perilaku tantrum yang terjadi pada anak sangat erat hubungannya dengan pola asuh orang tuanya. jika pola asuh yang diberikan orang tua pada anak kurang baik maka akan mempengaruhi munculnya prilaku tantrum pada anak. Seperti orang tua yang suka kurang peka terhadap lingkungan sekitar maka anak akan terbiasa acuh dan kurang responsive. Sebaliknya jika pola asuh itu baik maka menjadikan anak memiliki kepribadian yang kuat, tidak mudah putus. Salah satu keterampilan yang dapat digunakan oleh konselor untuk mengatasi hal ini adalah lukisan. Dalam konseling penggunaan seni telah tumbuh menjadi bentuk yang diterima sebagai sebuah terapi di kalangan anak-anak dan orang dewasa.

Konselor dalam sesi konseling harus memiliki berbagai keterampilan untuk membantu mengungkap permasalahan ataupun keinginan konseli, salah satu cara mengungkap permasalahan konseli dapat dilakukan menggunakan lukisan. Lukisan sangat tepat untuk mengepresikan berbagai hal yang sulit diungkapkan konseli secara verbal maupun tulisan. Konseling yang baik adalah dengan seni, karena lebih selaras dengan humaniora dibandingkan dengan ilmu pengetahuan.

\section{KAJIAN TEORI}

Pendidikan Anak Usia Dini (PAUD) merupakan tahapan pra dasar sebelum masuk pada pendidikan dasar. Pada jenjang PAUD ini menjadi tempatnya untuk pembinaan bagi anak sejak usia lahir sampai dengan enam tahun dengan memberikan rangsangan pendidikan 
sehingga akan membantu pertumbuhan dan perkembangan anak baik aspek jasmani maupun rohaninya. Anak merupakan unik karena memiliki karakteristik tertentu serta berbeda dengan orang dewasa (Mahyuddin, N., Hutasuhut, B. R. S., Cendana, H., Rahmawati, R., Natari, R., Aprilia, S., ... \& Uzlah, 2021). Proses Pelaksanaan pembelajaran di PAUD harus menitikberatkan pada peletakan fondasi dasar baik pertumbuhan maupun perkembangan fisik anak seperti dalam koordinasi motorik halus dan kasar. Kemampuan kecerdasan anak juga harus dioptimalkan baik berupa daya pikir, daya cipta, kecerdasan emosi, dan kecerdasan spiritual. Selain itu juga kemampuan bahasa dan komunikasi yang disesuaikan dengan keunikan dan tahap-tahap perkembangan yang dilalui oleh anak usia dini. Belajar bagi anak usia dini memiliki keunikan tersendiri, harus secara menyeluruh dan kontinyu tanpa paksaan, menyenangkan agar mampu menyesuaikan diri pada tingkatan selanjutnya (Lestariningrum, A., Lailiyah, N., Ridwan, R., Forijati, R., Wijaya, I. P., Wulansari, W., ... \& Dwiyanti, 2021).

Ditemukannya virus baru bernama corona dari sebuah wilayah di china yaitu wuhan membuat seluruh dunia terkena dampaknya termasuk indonesia. Virus ini adalah virus baru yang belum pernah di temukan sebelumnya dimanapun di seluruh dunia. Oleh sebab itu virus yang dinamakan Covid-19 ini berbahaya bahkan dapat menyebabkan kematian. Virus ini memiliki daya tahan yang kuat, virus ini dapat bertahan hingga 9 hari pada benda, dan 14 hari pada manusia tanpa adanya gejala. Setelah 14 hari baru akan memunculkan gejala sakit seperti demam, flu dan sesak nafas. Oleh sebab itu virus ini sangat mudah menular dalam waktu cepat. Setelah virus ini menyebar di wuhan dalam waktu 3 bulan saja virus covid-19 menyebar di seluruh dunia dan di tetapkan sebagai pandemi oleh WHO (Wolrd Health Organisations).

Kasus pertama covid-19 di Indonesia terdeteksi pada awal bulan Maret 2020 dengan temuan 12,776 kasus dan 930 kematian yang terjadi di 34 Provinsi. Meskipun demikian hanya 2\% saja yang dilaporkan dari temuan studi model di semua kasus infeksi, pertama, tanpa perawatan dan vaksin, dan kedua pandemi Covid-19 menjadi krisis kesehatan dunia. Banyak pembiasaan baru yang ditegakkan setelah pandemi covid-19 ini. Baik pemerintah pusat maupun daerah mengambil kebijakan tegas untuk mewajibkan libur sekolah. Hal serupa juga menjadi kebijakan yang sama oleh negara-negara lain yang sudah terlebih dahulu terkena dampak covid-19 yaitu dengan 
meniadakan seluruh aktivitas Pendidikan. Dengan adanya kebijakan tersebut maka seluruh pelaku di dunia pendidikan dituntut untuk kreatif dalam menghadirkan alternatif proses pendidikan bagi peserta didik. Seluruh lembaga pendidikan dilarang keras menyelenggarakan aktivitas pembelajaran seperti biasa, dengan harapan dapat menekan penyebaran penyakit Covid-19 ini.

Karantina lock down menjadi salah satu bentuk kebijakan untuk menekan lonjakan covid dengan harapan adanya pengurangan interaksi masyarakat pada penyebaran virus corona. Seperti, penutupan Bandara, penutupan sekolah, baik dari jenjang sekolah dasar sampai perguruan tinggi, penutupan toko, pemberlakuan WFH dan lain sebagainya.3 Salah satu dari banyak upaya pemerintah untuk mengurangi penyebaran covid-19 ini yaitu melaksanakan kebijakan untuk meliburkan seluruh aktivitas pendidikan dan menerapkan alternatif proses pendidikan bagi peserta didik maupun mahasiswa secara daring. Hal inilah yang membuat ana-anak menjadi bosan dan tantrum karena situasi pandemic saat ini yang mengharuskan mereka belajar dan berkegiatan hanya dirumah saja.

Lockdown juga berdampak menimbulkan lebih banyak beban bagi keluarga dan lembaga untuk memastikan pertumbuhan dan perkembangan anak. Anak-anak tidak dapat melakukan interaksi sosial di sekolah dan bermain di luar, dua hal penting untuk mendukung pembelajaran dan perkembangan mereka.9 Dampak lockdown juga terlihat pada banyaknya orang tua yang mengeluh terhadap anaknya yang kecanduan gadget, dari televisi, telepon genggam hingga tablet.

Anak usia dini, dulu sering disebut dengan anak usia Taman Kanak-Kanak, dimana usianya sekitar $4-6$ tahun. Pada usia ini merupakan usia yang potensial dalam pertumbuhan dan perkembangannya, karena pada pertumbuhan dan perkembangannya sangat pesat. Bahkan menurut ahli psikologi perkembangan Elizabeth Hurlock, mengatakan anak usia dini / TK ini masa keemasan, oleh karena itu factor lingkungan sangat berperan dalam memfasilitasi pembentukan perilaku anak, anak berperilaku baik atau buruk bagaimana lingkngan yang mempengaruhinya. 
Konseling merupakan proses untuk membantu konseli dalam menghadapi, memahami dan menerima diri, serta interaksi dengan individu lain agar dapat membuat penyelesaian-penyelesaian terhadap berbagai permasalahan kehidupan.

Anak adalah anugerah yang diberikan Tuhan kepada kita sebagai orang tua, dalam usia anak 4-6 Tahun adalah masa dimana anak masih menyesuaikan diri dengan lingkungannya sehingga ia merasa bahwa dirinya merupakan bagian dari lingkungan yang ada. Maka dari itu orang tua haruslah berhati-hati dalam memberikan contoh kepada anak dari situlah anak akan menirukannya. Anak yang terlahir kurang normal normal, sering kali dianggap merepotkan, hal ini tidaklah benar dan perlu diluruskan bahwa semua manusia dimata alloh itu sama (Khoirunnisa, 2020).

Menurut Eileen Hayes Tantrum adalah ledakan amarah yang terjadi pada usia 18 bulan sampai 6 tahun, seperti berbaring di lantai, kaki menendang-nendang, tangisan kecil untuk protes dan menangis dengan nada tinggi sebagai jenis tantrum yang paling ekstrem. Semua anak/balita kadang akan menjadi marah dan putus asa, tetapi tidak semua dari mereka menumpahkannya dengan teriakan.

Menurut Dra. Hastaning Sakti, Psi. M.Kes mengatakan Bahwa temper tantrum ini adalah sebuah fase yang memang selalu ada pada anak-anak, umumnya pada usia 3 sampai 4 tahun, dimana anak tengah ingin menunjukkan egonya. Terkadang, temper tantrum terjadi pula pada umur 9 hingga 10 tahun, di mana pada usia itu anak tengah ingin mencari jati diri, diakui di tengah-tengah lingkungannya.

Hurlock berpendapat bahwa anak yang dapat melumpuhkan emosi kemarahannya dengan wajar, maka anak akan menampakkan gambaran emosi yang tenang. Dalam konteks ini, emosi yang dimaksud adalah bagaimana cara anak untuk dapat mengendalikan emosinya yang umumnya saat marah, anak mengekspresikan emosinya dengan raut wajah, gaya tubuh, dan perkataan anak.

Anak yang berhasil mengelola emosinya pada kondisi tertentu, maka anak tersebut dinilai sudah mampu mengendalikan emosinya sendiri (emotional control). Namun, masih terdapat anak yang memiliki kegagalan dalam mengelola emosinya yang diakibatkan oleh banyak faktor. Mayoritas anak yang gagal dalam mengelola emosinya, seringkali menangis, merengek, menjerit, membanting atau merusak barang, menghentakkan kakinya maupun bergulingguling. Perilaku pada anak tersebut merupakan bentuk perilaku negatif dan emosi yang 
berlebihan atau disebut dengan temper tantrum. Orang tua memiliki peranan yang penting untuk dapat mendampingi, berusaha memberikan penanganan apabila anak terjadi kesalahan selama masa tumbuh kembang anak (Rif'ati, M. I., \& Suryanto, 2018).

Tantrum sering terjadi oleh anak, tetapi apabila hal ini tidak ditangani dengan tepat, maka dapat menimbulkan perilaku negatif pada anak seperti agresif dan menyakiti dirinya sendiri (self harm) maupun menyakiti orang lain di masa mendatang.dikutip dari (Rahayuningsih Sri I., 2014), mengungkapkan apabila perilaku tantrum pada anak terlambat untuk ditangani oleh orang tua, maka perilaku tantrum akan menjadi sifat yang menetap pada anak ketika menjelang dewasa. Orang tua maupun pendidik dituntut untuk dapat bertindak dengan tepat dalam mengatasi perilaku tantrum pada anak. Apabila orang tua dan pendidik keliru, maka mereka dapat kehilangan kesempatan dalam mengajarkan anak untuk dapat meluapkan emosinya secara normal, misalnya, marah, takut, kesal maupun kecewa

Orang tua bisa menjadi bingung karena permintaan si kecil yang merengek. Kadang-kadang, anak merengek untuk sesuatu, seperti "ingin es krim" atau "bacakan cerita lagi". Kadang-kadang, hal itu berupa rengekan yang lebih umum dan suasana hati yang buruk yang mungkin lebih parah akibat rasa lapar, lelah, atau munculnya penyakit. Apapun alasannya, merengek menyebabkan kebiasaan buruk yang akan meningkat menjadi tantrum. Orang tua harus terlibat menjadi hubungan utama dengan anak (Purba, D. H., Kartika, L., Supinganto, A., Hasnidar, H., Wahyuni, W., Sitanggang, Y. F., ... \& Hutapea, 2020).

Untuk mencegah terjadinya tantrum dengan mengenali kebiasaan-kebiasaan anak, dan mengetahui secara pasti pada kondisikondisi seperti apa yang muncul tantrum pada anak (Manuhutu, 2020).

Ada beberapa faktor yang dapat menyebabkan terjadinya tantrum diantaranya adalah terhalangnya keinginan anak mendapatkan sesuatu, ketidak mampuan anak mengungkapkan diri, tidak terpenuhinya kebutuhan, pola asuh orang tua, anak merasa lelah, lapar, atau dalam keadaan sakit, serta anak sedang stress. Orang tua pun aebetulnya dapat dilakukan terapi terkait dengan bagaimana cara atau proses mendidik anak yang memiliki gangguan (Manuhutu, 2020).

Tantrum juga dapat dipicu karena stress akibat tugas-tugas sekolah yang harus dikerjakan anak.dalam hal ini orang tua harus mendampingi anak pada saat dia mengerjakan tugas- 
tugasnya.kemudian dengan melihat bagaimana cara orang tua mengasuh anaknya.

Seni merupakan ungkapan rasa. Seni muncul di dalam diri seseorang dimana membuat seseorang akan merasakan kepuasan terhadap batinya dan terhadap apa yang dibuatnya (Nelson, 2016). Karya seni rupa yang dapat dihasilkan anak salah satunya adalah karya seni lukis. Beragam teknik lukis dapat diberikan oleh guru terhadap anak disesuaikan dengan tingkat perkembangannya. Salah satu kegiatan melukis yang dapat dilaksanakan oleh anak yaitu finger painting (Sundari, R., \& Zahro, 2021) .Selanjutnya berkesenian terutama melukis dapat dimanfaatkan untuk beragam hal salah satunya digunakan untuk terapi. Seni lukis sebagai stimulasi kreativitas anak (Hardiyanti, 2020). Hal ini difungsikan untuk mengembangkan kreativitas. Salah satu pemanfaatan seni lukis lainnya yaitu digunakan untuk terapi pada Pasien Skizofrenia dan Ketergantungan Narkoba (Anoviyanti, 2008). Beberapa penelitian menunjukan bahwa seni lukis dapat memiliki manfaat untuk membatu menurunkan depresi pada remaja hal tersebut salah satunya yaitu peneitian yang menunjukan bahwa melalui eksperimen melukis dapat menurunkan depresi bagi remaja (Shokiyah, N. N., \& Syamsiar, 2019).

\section{METODE PENELITIAN}

Penelitian ini menggunakan metode Observasi, wawancara, pemberian tugas dan dokumentasi. Subjek penelitian ini anak usia 6 tahun bernama M.Daffa Arzaq, konseling ini menggunakan metode konseling terapi melukis, dalam mengatasi tempra tantrum pada anak alat dab bahan yang dipakai dalam konseling ini yaitu cat air, dan kertas gambar.

\section{HASIL DAN PEMBAHASAN}

\section{A. Tantrum}

Temper trantum atau disebut tantrum, merupakan suatu luapan emosi yang tidak terkontrol pada anak, yang sering muncul pada anak tahap usia toddler. Pada tahap usia ini anak-anak sudah mulai mengenal dunia dengan cara merangkak, berjalan, dan sering sekali harus menghadapi konflik dengan orang dewasa disekitarnya. Konflik ini muncul seiring dengan adanya berbagai kemauan anak yang 
185

tidak dipahami atau dipenuhi oleh orangtua, sehingga sering kali orang tua merasa kerepotan pada tahap ini.

Ketika anak mengalami temper tantrum, anak-anak cenderung melampiaskan segala bentuk kemarahannya. Tingkah laku tantrum secara umum yang ditunjukkan anak dengan menangis keras, berteriak, menjerit-jerit, memukul, menggigit, mencubit, menendang, berontak, melempar badan ke lantai dan berlari menjauh. Perilaku tantrum tidak selamanya merupakan hal yang negatif bagi perkembangan anak, namun jika ditelaah lebih dalam, juga memiliki beberapa hal positif seperti anak memiliki keinginan menunjukkan independensinya, mulai mengekspresikan individualitasnya dalam mengemukakan pendapat, mengeluarkan rasa marah dan frustrasi, serta berusaha membuat orang dewasa atau orang tua mengerti saat anak merasa bingung, kelelahan atau sakit.

\section{B. Gejala Perilaku Tempra Tantrum}

Temper tantrum merupakan ledakan emosi yang kuat dan tidak terkontrol umumnya terjadi pada anak usia 2 tahun hingga 5 tahun, tantrum sendiri dibagi menjadi tiga jenis yaitu tantrum manipulasi, tantrum karena frustrasi verbal dan tantrum yang bersumber dari kondisi frustrasi anak yang diekspresikan lewat emosi kemarahan yang tak terkontrol.

Jenis tantrum yang pertama dilakukan anak untuk memanipulasi agar dirinya mencapai apa yang ia inginkan, dengan kata lain anak menganggap amukan sebagai senjata dirinya untuk mendapat apa yang ia inginkan. Anak kesal merasa ada sesuatu yang tak sesuai dengan hatinya, namun ia merasa kesulitan mengungkapkan perasaannya akhirnya anakpun uring-uringan tak jelas maka keadaan ini jenis tantrum yang kedua. Sedangkan tantrum yanh ketiga sangat terkait erat dengan temperamen anak, biasanya tantrum ini akan muncul saat anak merasa lelah atau mengalami kekecewaan yang amat berat.

\section{Cara Mengatasi Prilaku Tempra Tantrum Pada Anak}

Pada masa pandemi saat ini menjadikan anak-anak dan ibu-ibi menjadi bingung karena semua kegiatan dilakukan di dalam rumah, anak merasa bosan dengan banyak tugas,orang tuapun merasa beban yang sangat berat karena tanggung jawabnya bertambah saat anak belajar dirumah. 
Cara Mengatasi Tantrum pada Anak Tantrum pada anak tidak boleh dibiarkan terus-menerus karena bisa menjadi kebiasaan yang buruk dan memengaruhi perkembangannya di kemudian hari. Bunda bisa mencoba menghentikan tantrum pada anak dengan melakukan beberapa cara berikut:

\section{Tetap tenang}

Saat anak tantrum, Bunda harus tetap tenang dan jangan membalas berteriak atau memaksa anak menghentikan amukannya. Sikap yang tenang akan membuat tantrum Si Kecil lebih mudah untuk diatasi. Bunda juga bisa mengajak Si Kecil ke tempat yang lebih sepi dan tenang guna menenangkan emosinya.

\section{Cari tahu penyebab tantrum}

Beragam hal bisa menjadi penyebab tantrum pada anak, seperti keinginan yang tidak terpenuhi atau adanya perasaan lapar dan mengantuk yang sulit diungkapkan. Jika anak belum bisa berbicara, salah satu cara untuk mengenali penyebabnya adalah dengan menanyakan secara langsung, "Kamu lapar?" atau "Kamu masih ngantuk?". Anak mungkin akan mengangguk atau menggeleng. Jika penyebab tantrum anak diketahui, maka Bunda akan lebih mudah mengatasinya.

\section{Alihkan perhatian Si Kecil}

Anak kecil sangat mudah melupakan sesuatu dan tertarik pada hal baru. Bunda bisa memanfaatkan hal ini untuk mengalihkan perhatiannya saat tantrum. Misalnya, Bunda bisa memberikan mainan yang sudah lama tidak dimainkan atau memberikan camilan kesukaannya saat anak berteriak, marah, atau terlihat rewel.

\section{Jangan memukul anak}

Untuk mengatasi tantrum, pola asuh otoritatif lebih cocok untuk diterapkan. Jadi, jangan memukul atau mencubitnya. Ini justru dapat membuat anak jadi suka memukul untuk menyampaikan keinginannya. Sebagai gantinya, orang tua bisa memeluk atau mencium Si Kecil untuk menenangkan emosinya. Selain menenangkan, pelukan dan ciuman juga bisa menjadi cara untuk menunjukkan bahwa Bunda benar-benar peduli dan mencintai mereka.

Dalam hal ini Konselor memberikan solusi dalam permaslahan kasus tantrum pada anak ini yaitu dengan Salah satu cara orang tua mengatasi perilaku temper tantrum pada anak yaitu dengan cara melukis. 
Melalui melukis kreativitas anak khususnya dalam seni lukis dapat dikembangkan. M.Adler mengatakan bahwa seni lukis adalah sesuatu yang memberikan kesenangan.

Selain dengan cara melukis ada beberapa solusi untuk mengatasi anak tempra tantrumyaitu dengan mencegah terjadinya tantrum dengan cara mengenali pola tantrum anak dan strategi menghindari pemicu tantrum. Namun ketika tantrum berlangsung, maka strategi yang dapat dilakukan orang tua adalah bersikap tenang, pastikan keamanan anak, abaikan tantrum sementara, dan membendung kekacauan. Menangani anak pasca tantrum dengan cara menggunakan pujian, memaafkan dan melupakan.

\section{Hasil Konseling dengan Tehnik Melukis}

Pada tehnik melukis ini konseling berhasil menenangkan anak yang sedang menangis tersebut menggunakan media melukis. Berdasarkan hasil analisis terhadap kajian teori, dapat diambil garis besar bahwa modifikasi perilaku pada anak usia dini dapat mengurangi perilaku temper tantrum pada anak. Hal ini didukung dengan hasil penelitian yang menunjukan bahwa dengan metode melukis dapat mengurangi perilaku tantrum anak. Teknik melukis dapat menjadikan anak menjadi lebih tenang dan dapat mengekpresikan keinginanya. Teknik ini digunakan untuk mengurangi atau menghapus perilaku sasaran, terutama perilaku tantrum pada anak. Pada penerapannya, saat anak mengalami temper tantrum, maka anak segera dialihkan kepada hal-hal yang ia sukai seperti kegiatan melukis.

Malchiodi menyatakan bahwa sketsa, gambar, dan lukisan dapat digunakan dalam proses konseling art. Pemilihan intervensi artistik yang digunakan untuk konseling harus didasarkan pada isu-isu konseli dan model ekspresi diri yang konseli sukai. Berbagai jenis kegiatan yang melibatkan sketsa, menggambar, dan melukis hanya dibatasi oleh konselor dan imajinasi konseli. Salah satu teknik konseling yang digunakan dalam konseling art adalah menggambar.

Benson menyatakan bahwa gambar dapat membuat sensasi kesenangan, ketakutan, kecemasan, atau rasa tenang, dan ada bukti bahwa mereka dapat mengubah suasana hati dan bahkan menginduksi rasa kesejahteraan (keamanan, keselamatan, ketenteraman). 
Hal ini dilakukan agar perilaku tantrum pada anak dapat mereda seiring dengan anak dijauhkan dari pemicu perilaku tantrum nya. Hasil Penelitian juga memaparkan, bahwa melukis dapat membantu mengatasi anak dengan perilaku temper tantrum. Dalam penelitian ini, memaparkan bahwa dengan adanya teknik melukis i dapat mengurangi perilaku tantrum pada anak. Penerapan teknik di atas dapat diterapkan dengan cara anak melakukan kegiatan bermain sesuai tahap perkembangannya.

\section{KESIMPULAN}

Covid-19 telah resmi menjadi pandemi di Dunia. Semejak di tetapkannya pandemi ini banyak sekali aktivitas yang berubah mulai dari aktivitas pekerjaan, aktivitas sekolah bahkan kehidupan seharihari pun berubah. Aktivitas di rumah saja berdampak cukup besar kepada siswa, diantaranya adalah mereka harus belajar dari rumah. Belajar dari rumah secara online membuat siswa harus beradaptasi secara ekstrim perubahan gaya belajar mereka Menurut Eileen Hayes Tantrum adalah ledakan amarah yang terjadi pada usia 18 bulan sampai 6 tahun, seperti berbaring di lantai, kaki menendang-nendang, tangisan kecil untuk protes dan menangis dengan nada tinggi sebagai jenis tantrum yang paling ekstrem. Cara Mengatasi Tantrum pada Anak Tantrum pada anak tidak boleh dibiarkan terus-menerus karena bisa menjadi kebiasaan yang buruk dan memengaruhi perkembangannya di kemudian hari.

Pada penelitian ini subyek menangis karena tidak ingin mengerjakan tugas dan ingin memandikan ayamnya, akan tetapi orangtuanya mencegahnya sehingga ia menangis dan melemparlempar barang yang ada di sekitarnya. Dalam penelitian ini konseling memberikan terapi Melukis Pada subyek dan subyek merespon dengan baik. melukis dapat mengurangi perilaku tantrum anak. Teknik melukis dapat menjadikan anak menjadi lebih tenang dan dapat mengekpresikan keinginanya. 


\section{DAFTAR PUSTAKA}

Anoviyanti, S. R. (2008). Terapi Seni Melalui Melukis pada Pasien Skizofrenia dan Ketergantungan Narkoba. Journal of Visual Art and Design, 2(1), 72-84.

Hardiyanti, W. D. (2020). Aplikasi bermain berdasarkan kegiatan seni

lukis untuk stimulasi kreativitas anak usia 5-6 tahun. Jurnal Pendidikan Anak, 9(2), 134-139.

Khoirunnisa, N. (2020). IMPLEMENTASI KEGIATAN TERAPI AL-QUR'AN DALAM MEMBENTUK SPIRITUALITAS SISWA.

Lestariningrum, A., Lailiyah, N., Ridwan, R., Forijati, R., Wijaya, I. P.,

Wulansari, W., ... \& Dwiyanti, L. (2021). Inovasi Pembelajaran Anak Usia Dini.

Mahyuddin, N., Hutasuhut, B. R. S., Cendana, H., Rahmawati, R., Natari,

R., Aprilia, S., ... \& Uzlah, U. (2021). Modul Pembelajaran Sains Anak Usia Dini untuk Anak TK 4-6 Tahun. CV. DOTPLUS Publisher.

Manuhutu, V. N. B. (2020). EKNIK KOMUNIKASI PERSUASI PENGURUS HARIAN "PUSAT TERAPI PERMATA ANANDA" PADA ORANG TUA SISWA TERKAIT PROSES PENDIDIKAN ANAK PENYANDANG GANGGUAN SPEKTRUM AUTISTIK.

Nelson, N. (2016). Kreativitas dan Motivasi dalam Pembelajaran Seni Lukis. NUSANTARA: Jurnal Ilmu Pengetahuan Sosial, 1(1).

Purba, D. H., Kartika, L., Supinganto, A., Hasnidar, H., Wahyuni, W., Sitanggang, Y. F., ... \& Hutapea, A. D. (2020). Ilmu Kesehatan Anak. Yayasan Kita Menulis. 
Rahayuningsih Sri I. (2014). STRATEGI IBU MENGATASI PERILAKU

TEMPER TANTRUM PADA ANAK USIA TODDLER DI RUMAH SUSUN KEUDAH KOTA BANDA ACEH. 5(1). Retrieved from

file://C:/Users/niam/Downloads/Documents/1511-2845-1SM.pdf.

Rif'ati, M. I., \& Suryanto, S. (2018). Pola Regulasi Emosi Orang Tua Dengan Anak Temper Tantrum.

Shokiyah, N. N., \& Syamsiar, S. (2019). TERAPI MELUKIS UNTUK MEMBANTU MENURUNKAN DEPRESI PADA REMAJA.

Sundari, R., \& Zahro, F. (2021). Peningkatan Kreativitas Melalui Pelatihan Finger Painting Bagi Guru PAUD. Journal of Early Childhood and Character Education, 1(1), 73-90. 